\title{
Impairment of Assets Under Perspectives of International and Vietnamese Accounting
}

\author{
Thi Thu Trang Nguyen Thi Thuy Trang Vu Dang Hai Ha Pham Vuong Thuy Anh Nguyen \\ Advanced Accounting 58B, National Economics University, Vietnam \\ Manh Dung Tran \\ National Economics University, Vietnam
}

\begin{abstract}
This study investigates the impairment of assets on financial reportings of three separate entities - Vietnam Prosperity Joint-Stock Commercial Bank (VPBank), The Bank of East Asia (BEA) and The Nestlé Group - in the financial year of 2017. By bringing out the differences between international accounting system of asset impairment (IAS 36) and Vietnamese accounting system (VAS), this research has determined the gap between two sets of financial statements under IFRS and VAS in conveying the business performance and financial position. The empirical results show Vietnam's necessary for a convergence in asset impairment with international accounting system. Therefore, we provide some recommendations for Vietnam in applying asset impairment regarding to IAS 36 partly or completely.
\end{abstract}

Keywords: Asset impairment, International accounting, Vietnamese accounting.

DOI: $10.7176 / \mathrm{RJFA} / 10-12-07$

Publication date:June $30^{\text {th }} 2019$

\section{Introduction}

In the last few decades, Vietnam economy is integrating with the global economy and is in its period of rapid development. Vietnam has entered numerous international organizations in business and opened the market widely for foreign investment. However, Vietnamese accounting system has many differences from international accounting system. Here comes IFRS that is now adopted by more than 140 countries most of which is dominant countries.

During the operating process of any firm, the asset impairment is an inevitable possibility to the firm's assets due to volatile factors inside and outside the firm. Asset impairment recognition helps firms in both risk management and accounting. However, the standard of assets impairment has not yet been issued in Vietnam, as well as its recognition and measurement. Instead, assets are recorded under the accounting principle. During the useful lives, assets are recorded at their historical cost and are not be revalued. If the impairment of assets is not recognized, the financial statements cannot retain the reliability.

The challenge for Vietnam when recognizing asset impairment is that our stock market is extremely young, and there is little reference data as well as the guidance of fair value measurement. Consequently, in Vietnam, there are significant differences in financial reporting about the impairment of assets between a firm which is in compliance with IFRS and which is in compliance with VAS. Our study investigates in this difference by analyzing the consolidated financial statement of some groups.

Recently, Vietnam has embarked on market economy, and our economy has been in accelerated growth to obtain a substantial development. Accordingly, the ineligible regulation needs to be altered by a more appropriate one regarding to the current situation in the country and in the world. Through this study, we encouraged Vietnamese accounting system to align itself with IFRS and gave some recommendations for this convergence.

\section{Literature Review}

The problem of impairment of assets had been mentioned and studied for a long time. Many authors believed that depreciation had not reflected all the current values of assets in the enterprise. Assets impairment should be recognized in accounting standards.

In the world, many researchers paid attention to dominant motivation for recording impairment of assets and management quality of firms. Strong and Meyer (1987) pointed out that there is no difference in the financial situation between firms recognized assets impairment and firms not used. Besides, Minnick (2004) pointed out that the quality of corporate governance has a positive relationship with the decision to reduce asset value. If the company has weak governance, it will avoid or delay assets impairment operations.

On the other hand, many types of research showed the level of compliance to accounting standards (IAS 36) on assets impairment of firms. The research of Carlin and Finch (2010) detected the existed behaviors of intentionally omitting the value of asset impairment in order to increase the profits of enterprises in these two countries. Tran (2011) focused on the low-level compliance to accounting the impairment of goodwill of listed 
firms in Hong Kong. Also, Tran et al. (2013) studied the compliance and quality of companies in Singapore while Kanakriyah (2012) investigated in Jordan.

In addition, many authors concerned that the reversal of asset value which had decreased when there were some signs of economic recovery affected the decision to do impairment of assets. Kristina et al. (2013) pointed out whether using an alternative accounting method to allow reverse asset values to be affected by the decision of the manager to reduce asset value. Zhang et al. (2010) investigated the promulgation of Chinese regulations affecting the decision to reduce the value of assets of listed firms on the Chinese stock market.

In Vietnam, few studies on impairment of assets and its application can be found. First of all, Mai (2012) analyzed the decline in fair value of assets as an early warning signal for businesses when the economy is difficult or has the risk of financial crisis. Tran (2014) concludes the compliance with the standards assessed at the tower level (average values from 2.46 to 2.90). Moreover, some recent studies discuss issues related to IAS 36 and raising the need to implement in Vietnam. Chu (2013) showed VAS and international accounting systems as well as some solutions for Vietnamese system. $\mathrm{Vu}$ (2014) pointed out that there is no specific regulation on the recognition and presentation of accounting information on impairment of assets, which affects decisionmaking. Besides, Dang (2017) pointed out the current situation of accounting of reserves and impairment of assets in construction firms. Nguyen (2010) analyzes the gap between Vietnamese and international accounting standards, the impact of such differences on accounting information on financial statements and solutions appropriate to the Vietnamese environment. Also, Le (2014) assessed the current status of financial reporting, limitations with international standards, offering advanced solutions to improve the usefulness of information on financial statements. In general, most research in Vietnam indicates the need to enact a new standard about impairment of assets.

\section{Cases of Asset Impairment}

This research has studied on three firms, including a Bank in Vietnam and two multinational enterprises. We use the desk review and collect data related to impairment asset of firms, especially goodwill impairment. Therefore, we clarify the issues relating to asset impairment in Vietnam and then compare with international one. Then we show the differences and come to conclusions regarding to a convergence of VAS with IFRS.

\subsection{Case of Vietnam Prosperity Joint-Stock Commercial Bank (VPBank)}

Vietnam Prosperity Joint Stock Commercial Bank (VPBank) was one of the first banks established in Vietnam in August 12, 1993. VPBank has a network of over 200 bank agencies with nearly 24,000 employees. Its development objective is a dynamic image with an abundance financial capacity. They want to become one of the top 5 joint-stock commercial banks in Vietnam and one of the top 3 retail banks in Vietnam in 2017.

\subsubsection{Impairment of Assets of VPBank under VAS}

Table 1 shows the notes for the allocation of goodwill amortization from the mid-year of 2014 to the end of 2017. In accordance with IAS 11, VPBank chose 3 years as the estimated useful life of the goodwill. According to VPBank's consolidated financial statements, the subsidiary was acquired at 2014 mid-year, so the total value of goodwill is completely amortized at 2017 mid-year. The value of goodwill amortized in the fiscal year 2015 is equal to its in 2016 (VND 24,968 million) while goodwill amortized in 2014 and 2017 is equal to VND 12,485 million.

Table 1: Changes in the value of goodwill in VPBank from 2014 to 2017

\begin{tabular}{|c|c|c|c|c|}
\hline \multicolumn{5}{|c|}{ Unit: Million d } \\
\hline Goodwill & 2017 & 2016 & 2015 & 2014 \\
\hline Total value of goodwill & 74,905 & 74,905 & 74,905 & 74,905 \\
\hline $\begin{array}{l}\text { Value of accumulated amortized goodwill at the beginning } \\
\text { of the year }\end{array}$ & $(62,420)$ & $(37,452)$ & $(12,484)$ & - \\
\hline $\begin{array}{l}\text { Value of accumulated unamortized goodwill at the } \\
\text { beginning of the year }\end{array}$ & 12,485 & 37,453 & 62,421 & - \\
\hline Increase in goodwill during the year & - & - & - & 74,905 \\
\hline Goodwill arise during the year & - & - & - & 74,905 \\
\hline $\begin{array}{l}\text { Adjustment due to changes in determinable value of assets } \\
\text { and liabilities }\end{array}$ & . & - & - & \\
\hline Decrease in goodwill during the year & $(12,485)$ & $(24,968)$ & $(24,968)$ & $(12,484)$ \\
\hline $\begin{array}{l}\text { Decrease in goodwill due to disposal, sale of part or entire } \\
\text { financial institution }\end{array}$ & & & & \\
\hline Goodwill amortized during the year & $(12,485)$ & $(24,968)$ & $(24,968)$ & $(12,484)$ \\
\hline Other amortized in goodwill & - & - & - & - \\
\hline Total value of unamortized goodwill at the year end & - & 12,485 & 37,453 & 62,421 \\
\hline
\end{tabular}

(Source: Note 17 in Consolidated Financial Statements of VPBank from 2014 to 2017) 
During four-year period, the values of increase in goodwill during the year are equal to zero, which means no other goodwill is recognized. Neither subsidiary is consolidated into VPBank nor the value of Vinacomin goodwill increases. Adjustment for changes in determinable value of assets and liabilities is disclosed in the notes with no value for three years, which means there is no goodwill impairment recognized.

In addition, VPBank also recorded expenses such as taxes, personnel expense, fixed assets expenses, etc. Based on Circular No. 200/2014 of Ministry of Finance, the annual amortization is recorded as General and Administrative Expense. In VPBank case, goodwill's allocation may be recorded in Other Administrative Expense. But there is no goodwill impairment recognized or goodwill impairment is less than the value of goodwill allocation each year from 2014 to 2017.

\subsubsection{Impairment of Assets of VPBank under IFRS}

In VPBank, purchase method of accounting is applied. If the cost of acquisition is less than the fair values of the identifiable net assets, this discount will be recognized directly to the consolidated statement of profit or loss in the period of acquisition.

According to VP Bank's financial statements under IFRS, VP Bank has mentioned policies related to the impairment of financial assets and non-financial assets. However, the impairment of financial assets is mentioned in the IAS 39, so they will be explained in this paper. For other asset, from beginning prepare the Financial Statement under IFRS, VPBank has not recognized any impairment loss of any asset. For goodwill, formed from July 1, 2014, from the acquisition of 100\% equity of the The VPBank Finance Limited Company, at the end of 2017, goodwill still retains its value without any impairment.

Because goodwill has an indefinite useful life, it is not allocated but only assessed impairment (if any). Although, the firm affirmed that goodwill has not impaired, this equability is not reflected in the financial statement through Cash - generating units (CGU).

\subsection{Case of The Bank of East Asia (BEA)}

Bank of East Asia (BEA) is one of Hong Kong's biggest Chinese-owned banks. It is ranked in the top five banks in terms of deposits, and the top ten in terms of its loan portfolio in the city. It has a long list of achievements rewarding for their outstanding banking service.

In the case of BEA in 2017, the Group conducted the testing impairment to evaluate whether the indications of impairment exist, and four types of assets are considered to be impaired, including Loans and Receivables, Available- for- sale financial assets, Assets held for sale and Intangible assets. Because the study considers in the scope of IAS 36, it focuses on the impairment losses of intangible asset. In the Group, calculation of recoverable amount of CGU is based on value in use. It uses cash flow projection in 5-year period. The discount rate used for value-in-use calculations is $8.6 \%(2016: 7.6 \%)$ and the long-term growth rate is $1.9 \%(2016: 1.9 \%-5.8 \%)$.

\subsubsection{Impairment of goodwill}

Table 2: BEA's changes in the carrying amount of goodwill in 2016 and 2017

\section{Unit: HKS million}

\begin{tabular}{lrr}
\hline & $\mathbf{2 0 1 7}$ & $\mathbf{2 0 1 6}$ \\
\hline At 1st January & 1,474 & 2,685 \\
Audit adjustment & - & $(6)$ \\
Exercise option & - & $(7)$ \\
Reversal due to disposal & - & $(33)$ \\
Transfer to asset classified as assets held for sale & - & $(1,149)$ \\
Exchange adjustments & - & $(16)$ \\
At 31st December & 1,474 & 1,474
\end{tabular}

(Source: Note 34 of Financial Statement in Annual Report 2017 of the Bank of East Asia)

BEA allocated goodwill to each CGU or group of CGUs, based on business segment, including personal banking, corporate banking, treasury banking and others. The estimation and measurement of goodwill allocation is tested annually. The carrying amount of goodwill had reduced by HK\$1,211 million from the beginning of 2016 to the end of 2017. However, this decline is not due to the impairment of CGU or group of CGUs, but rather due to Audit adjustment, Exercise option, Reversal due to disposal, Transfer to asset classified as assets held for sale and Exchange adjustments. During 2017, the value of CGU or group of CGUs did not change, so goodwill is not impaired. 


\section{Cost}

At 1st January

Exchange adjustments

At 31st December

\section{Accumulated amortization}

At 1st January

Amortization charge for the year

At 31st December

Impairment allowance

At 1st January

Charge for the year

At 31st December

Carrying amount at $31^{\text {st }}$ December

(Source: Note 34 of Financial Statement in Annual Report 2017 of The Bank of East Asia)

Intangible assets, consisting of building naming rights only, have a change in the carrying amount from the beginning of 2016 to the end of 2017. The most dominant effect is the charge of HK\$ 650 million. This charge is caused by the impact of government's policy on advertising billboards, which causes impairment losses on a building's naming right. It is recorded in the consolidated income statement as other operating expenses.

In particular, BEA allocated these impairment losses to reportable segment in Note 23 of Annual report 2017. The Group divided it businesses into nine reportable segments by business lines and geography. Hong Kong banking operations has 6 segments, including Personal banking, Corporate banking, Treasury markets, Wealth management, Financial institutions and other Hong Kong banking operations. Not belong to Hong Kong, the other banking operations are Mainland China operations, Overseas operations and Corporate services. These impairment losses of HK\$ 650 million derived from the only segment, Mainland China operations which the naming right is belong to.

In general, Cash flow statement is not affected by impairment losses because impairment losses transactions do not use cash. However, in case, the recognition for impairment losses in the cash flow statement was made by the indirect method is used.

\subsection{Case of The Nestlé Group}

The Société des Produits Nestlé S.A. is a food and beverage company in Switzerland. With continuous efforts, Nestlé was awarded and recognized in many prestigious awards in the world in 2017. Our research based on the 2017 Consolidated Financial Statement of the Group to study. In the 2017 Nestlé Consolidated Financial Statement, the Group has show the impairment test process and impairment charge of property, plant and equipment, goodwill, and intangible assets in accordance with IAS 36.

\subsubsection{Impairment of property, plant and equipment}

In the case of property, plant and equipment impairment, the Group showed the movement of property, plant and equipment in the table of Note 8 Property, Plant and Equipment in the Group's consolidated annual financial statement. The Group presented how to calculate net PP\&E at the end of 2017 in the table in the consolidated financial statement. Net PP\&E is the value of gross value less accumulated depreciation and impairments. However, the impairment testing was not mentioned but the reason causing the impairment loss of property, plant and equipment was explained. In 2017, the Group eliminated and sold inefficient production facilities, mainly related to Nestlé Skin Health, with the aim of improving, enhancing and optimizing industrial production 
capacity, which caused the impairment loss of Property, Plant and Equipment.

Nestlé also allocated impairment of property, plant and equipment by operating segment and products in the consolidated financial statement. The impairment loss were allocated by operating segment by five reportable operating segments, including Zone Europe; Zone Americas; Zone Asia, Oceania and sub- Saharan Africa; Nestlé Waters and Nestlé Nutrition and Other business and allocated by products by seven product groups which represent seven categories of Nestlé's business products, including Powdered and Liquid Beverages; Water; Milk products and Ice cream; Nutrition and Health Science; Prepared dishes and cooking aids; Confectionery and PetCare.

\subsubsection{Impairment of Goodwill and Intangible Assets}

(i) Impairment loss of Goodwill and Intangible Assets

In terms of impairment losses, Nestlé recognized that the carrying amount of goodwill and intangible assets are impaired in 2017, in Note 9 of the consolidated financial statement. In particular, impairment loss of goodwill is CHF 3,033 million and of intangible assets is CHF 158 million. Goodwill is not amortized but rather tested for impairment annually. On the acquisition date, goodwill from acquiring the business was allocated to each of the cash-generating unit. Like property, plant and equipment, Nestlé also expressed the impairment allocation of goodwill and intangible assets by operating segment and products in the table in the financial statements.

\section{(ii) Impairment test of goodwill and intangible asset}

The testing process was presented in detail in the Nestlé's consolidated financial statement. The impairment test of Nestlé was performed as the process mentioned in IAS 36. First, the Group allocated the asset to CGUs or groups of CGUs. According to 2017 Consolidated Financial Statement, Nestlé assets is allocated to more than 200 items of goodwill and intangible asset (with indefinite useful life), which allocated to more than 50 Cash Generating Units (CGU). In the Financial Statement, the Group has pointed out five CGUs which has significant effect with both goodwill and intangible assets with indefinite useful life: Wyeth Infant Nutrition, PetCare Zone AMS, Nestlé Skin Health, DSD for Frozen Pizza and Ice Crem-USA and Nestlé Infant Nutrition.

After testing process, for each CGUs, except for Nestlé Skin Health, the recoverable amount is higher than their carrying amount. The recoverable amount has been determined depending on a value-in-use calculation. According to the standard IAS 36, if "no basis for making a reliable estimate of the price at which an orderly transaction to sell the asset would take place between market participants at the measurement date under current market conditions", the company can calculate the recoverable amount by value-in-use which is true with the Nestle' situation. By using a steady or declining terminal growth rate and discounted at a pre-tax weighted average rate, the Group have been extrapolated that cash flows from these CGUs have been projected over the next 5 year. These key assumptions for each significant CGU are represented in detail in the 2017 financial statement as the table 4

Table 4: TheNestlé's key assumptions of significant CGUs

\begin{tabular}{|c|c|c|c|c|c|}
\hline 2017 & $\begin{array}{c}\text { Period of } \\
\text { cash flow } \\
\text { projections }\end{array}$ & $\begin{array}{l}\text { Annual } \\
\text { sales } \\
\text { growth }\end{array}$ & $\begin{array}{c}\text { Annual } \\
\text { margin } \\
\text { evolution }\end{array}$ & $\begin{array}{c}\text { Terminal } \\
\text { growth rate }\end{array}$ & $\begin{array}{c}\text { Pre-tax } \\
\text { discount } \\
\text { rate }\end{array}$ \\
\hline Wyeth Infant Nutrition & 5 years & $-1 \%$ to $6 \%$ & Stable & $3.2 \%$ & $8.0 \%$ \\
\hline PetCare Zone AMS & 5 years & $2 \%$ to $4 \%$ & Declining & $2.0 \%$ & $9.0 \%$ \\
\hline Nestlé Skin Health & 5 years & $4 \%$ to $7 \%$ & Improvement & $2.3 \%$ & $8.7 \%$ \\
\hline $\begin{array}{l}\text { DSD for Frozen Pizza and Ice } \\
\text { Cream-USA }\end{array}$ & 5 years & $-1 \%$ to $0 \%$ & Improvement & $1.8 \%$ & $8.7 \%$ \\
\hline Nestlé Infant Nutrition & 5 years & $1 \%$ to $4 \%$ & Improvement & $3.5 \%$ & $11.6 \%$ \\
\hline
\end{tabular}

\section{(Source: Note 9.1.2, 2017 Nestlé Consolidated Financial Statement)}

As the note of Consolidated Financial Statement, Nestle have determined the pre-tax discount rates depending on external sources of information. Based on past performance and current initiatives, the cash flows for the first five years were determined. The terminal growth rates have been ascertained to reflect the long-term view of the nominal evolution of the business.

Nestlé' management believes that any of the above important assumptions cannot occur with any reasonable change that would cause the recoverable amount of the CGU to fall below the carrying value of the CGU. However, the negative changes of the CGU Nestlé Skin Health and the changes of CGU DSD for Frozen Pizza and Ice Cream - USA in the key assumptions would lead to the fault results; with one lead to a further impairment and the other lead to a situation where the carrying amount equals the value in use. Therefore, it can be inferred that the mainly impairment charge of the Group during the year 2017 is created by CGU Nestlé Skin Health. This information is fully explained in the financial statement.

\subsubsection{Impairment Charges}

Based on the Nestlé Consolidated Financial Statement in 2017, in section 9.1.1 - Impairment charge during the year, the Group determined that mainly the impairment charge during the year 2017 is taken responsibility by Nestlé Skin Health CGU and the small remaining loss is related to other various non-significant impairment of 
goodwill (primarily in Zone AOA) and intangible assets (primarily in Unallocated items). The Nestlé Skin Health CGU is included mainly of goodwill and intangible assets. Consequently, the predominant impairment charge of goodwill and intangible asset with indefinite useful life are caused by the impairment of Nestlé Skin Health CGU.

According to the significant policies of the Group following IFRS, the annual impairment test for the Nestlé Skin Health CGU was performed in the end of the year. The Group carried out the impairment test based on financial projections prepared after Nestlé Skin Health's new management completed a strategy review. The review considered the maturity and competitive environment of the worldwide skincare market and the mixed results created by the recent new products launches, brand or geographic expansion. The analysis sped up significant changes in Nestlé Skin Health's portfolio and focus causing to substantial restructuring activities initiated in late 2017. They explained for the modification of forecasted sales and margins and the reduction of the period of cash flows projection to 5 years.

\section{Discussion}

The analysis of VP Bank's consolidated financial statements in accordance with Vietnamese Accounting Standards and International Accounting standards shows the differences in business results and financial ratios of firms between the application and non-application of IAS 36. In particular, the lack of asset impairment recognition leads to an inaccurate reflection of the firm's asset value in the financial statements. The impairment charge changes some items on the financial statements and then affects the financial ratios. Table 5 shows the influence of the impairment loss in some financial ratios.

Table 5: The effect of impairment loss to ratios

\begin{tabular}{lcc}
\hline Ratios & Impairment loss & No Impairment charge \\
\hline Total Asset Turnover & High & Low \\
Fixed Asset Turnover & High & Low \\
Operating Profit Margin & Low & High \\
Net Profit Margin & Low & High \\
Return on Assets & Low & High \\
Pre-tax Margin & Low & High \\
Operating Return on Assets & Low & High \\
Return on Total Capital & Low & High \\
\hline
\end{tabular}

( Source: Compiled by the authors)

In the long term, the lack of transparency and heterogeneity between Vietnamese Accounting Standards and International Accounting Standards can make investors, especially foreign investors, uncertain about their investment in some businesses in Vietnam. This makes some difficulties for investors to forecast the future benefits of businesses. For Vietnamese firms, this is a barrier in the way to international integration while the International Financial Reporting Standards (IFRS) have been applied in more than 140 countries around the world.

Currently, the application level of IAS 36 in Vietnam is much sketchier than that of international firms. In can be seen through the consolidated financial statements of VPBank, Bank of Eastern Asia and Nestlé. On VPBank's financial statement for the financial year 2015, not any impairment losses of assets are recorded in the scope of IAS 36. The allocation of goodwill and intangible assets to CGU or group of CGUs was not mentioned in the consolidated financial statements, not as required by IAS 36. VPBank also did not present the process of impairment testing as well as the indicators affecting the process. These may also lead to a suspicion about whether the company actually tested the impairment of assets or not.

In contrast, the impairment testing and the calculation of impairment losses were fully disclosed on the consolidated financial statements of two international firms, as IAS 36 requirement. The Hong Kong BEA's financial statement showed the allocation of goodwill by CGU and the impairment testing process as well as the index measurement to calculate the impairment, including discount rate and growth rate, while their goodwill did not have any impairment loss. About the evaluation of asset impairment of intangible assets, the group did not present as clearly as the impairment of goodwill. It was only mentioned as an expense on the table of value changes of the intangible assets in 2017 and explained the reasons in the note below. The BEA also allocated the 
impairment of intangible assets regarding to segments and presented this impairment on consolidated financial statements. In general, their presentation of asset impairment of corporate is adequate. In comparison with the BEA, Nestlé's level of compliance with IAS 36 is much higher. Its impairment testing was fully described in the company policy, including the impairment of PP\&E, goodwill and intangible assets. The allocation of goodwill and intangible assets into significant CGUs and other CGUs are clearly presented. The method of calculating those indexes was mentioned on notes to the financial statement. In addition, the dominant event that caused impairment losses was also explained through the process of the impairment testing. The impairment losses are fully reflected on the income statement and the cash flow statement. The Group allocated impairment items by related segments and products. Such presentation will reduce the possibility of financial fraud and ensure the confidence of users on the business' results on financial statements.

The first reason for the lack of standards and difficulties in making financial reports in Vietnam, according to Luong, Director of Auditing Services, PwC Vietnam, is incomplete mechanisms and policies for applying IFRS in Vietnam. Due to the difference about the economic environment and the legal system, some IFRS requirements neither have a legal basis to record nor provide specific guidance, especially to determine the fair value of assets and impairment assets. The second reason is that Vietnamese human resources in accounting are not strong enough to fully understand and apply IFRS standards for approaching the development of international systems (Chu, 2013).Therefore, there are few Vietnamese firms preparing financial statements under international accounting standards.

It seems challenging for Vietnam in the way to a convergence of Vietnamese accounting standards with international accounting standards. Assoc. Prof. Vo and M.S. Le (2012) pointed out that Vietnamese culture makes them tend to avoid risks and uncertainty. Therefore, Vietnam mainly uses the cost method. Meanwhile, IFRS aims to measure assets by estimating fair value in order to ensure the relevance of accounting information, so the level of uncertainty is very high. In addition, having such a complex and reasonable accounting system like IFRS to serve the capital market is not Vietnam's urgent need (Vo and Le, 2012). For the market economy of Vietnam is still young, the requirement for financial reporting to serve investors is not as strict as its of IFRS. Vietnam has legal system of civil law, which is very different from common laws of most countries applying IFRS in the world. The Vietnamese accounting system must be corresponding to Vietnamese law and economic environment. It is difficult to fully apply IFRS in financial reporting in Vietnam. Therefore, the Vietnamese accounting standards were issued based on IFRS in a selective way to suit Vietnam's economic situation.

In short, a recent study of the integration of Vietnamese accounting standards with IFRS corresponding standards has shown that the level of integration of accounting standards related to assets is lower than that of accounting standards related to revenue and costs (Pham, 2010). This is mostly caused by that Vietnam has not yet had a standard of asset impairment.

The application of IFRS in financial reporting is necessary for promoting the development of Vietnamese firms, especially for attracting investment capital as well as increasing international competitiveness. In conclusion, the promulgation of a standard of asset impairment is necessary for Vietnamese firms' development as well as increase the integration of Vietnamese accounting standards with international accounting standards.

\section{References}

BEA. (2017). Annual Report. Retrieved from https:/www.hkbea.com/html/en/bea-aboutbea-investorcommunication-annual-and-interim-reports.

Carlin, T., \& Finch, N. (2010). "Evidence on IFRS goodwill impairment testing by Australian and New Zealand firms". Managerial Finance, 36(9), 785-798.

Chu, T.A. (2013). IAS 36 Standard and conditions for applying IAS 36 standards in Vietnam. University of Technology, Ho Chi Minh City, Viet Nam.

Dang, T.H.H. (2017). Complete accounting of reserves and impairment of assets in firms. Academy of Finance, Vietnam.

Deloitte (2018) IAS 36- Impairment of Assets. Retrieved from https://www.iasplus.com/en/standards

Kanakriyah. R.M, (2013) The effect of Asset Impairment (IAS 36) in Improving the Quality of Accounting Information According to Users' Perspective: Evidence from Jordan. Doctoral thesis, Durham University.

Kristina, R., Kathy, R., Seybert, N. (2013). Impaired Judgment: The Effects of Asset Impairment Reversibility and Cognitive Dissonance of Future Investment. http://ssrn.com, download April 2013.

Le, H.P. (2014). Applying international accounting standards to improve the system of corporate financial statements in Vietnam. Economics Doctoral thesis. University of Economics Ho Chi Minh City.

Luong, T.A.T. (2017). Upgrade accounting standards: Benefits and challenges. Securities Investment. Retrieved from https://tinnhanhchungkhoan.vn/chung-khoan.

Mai, N.A. (2012). Accounting by fair value and financial crisis. Journal of Auditing Scientific Research, 54, 1522.

Minnick, K. (2004). Write-offs and corporate governance. Working Paper. University of Maryland. Available at 
http://ssrn.com/abstract $=562950$

Nestlé. (2017). Consolidated Financial Statements. Retrieved from https://www.Nestlé.com/investors

Nguyen, T.L. H. (2010). Analysis influences the difference in Vietnamese accounting standards with international accounting standards to decisions of investors. Economic Master thesis. University of Economics Ho Chi Minh City.

Strong, John S. and Meyer, John R., 'Asset Writedowns: Managerial Incentives and Security Returns,' The Journal of Finance (Vol. 42, Issue 3, 1987), pp. 643-661.

Tran, M.D. (2011). Goodwill Impairment: The Case of Hong Kong, Doctor Thesis. Macquarie Graduate School of Management. Macquarie University, Sydney Australia.

Tran, M.D, Khairi, KF \& Laili, NH, (2013). Comparison of Discount Rates Disclosure Analysis in Goodwill Impairment Testing among Singapore Listed Firms, Journal of Economics and Development.

Tran, M.D., Tran, T.T, Pham, D.C. (2014). Compliance levels of goodwill impairment testing in Hong Kong: The lessons learnt for Vietnam. Research university level. National Economics University.

Vo \& Le. (2012). Convergence of VAS and IAS-Situation, reasons and development tendency. Retrieved from https://www.sav.gov.vn

$\mathrm{Vu}, \mathrm{T} . \mathrm{K} . \mathrm{A}$. (2014). Impairment tangible fixed assets, the reasonableness of presenting information on financial statements at Vietnamese firms today. Journal of Accounting and Auditing, 12, 22-25.

VPBank. (2014, 2015, 2016, 2017). Consolidated Financial Statements. Retrieved from https://www.vpbank.com.vn/bai-viet/bao-cao-tai-chinh.

aZhang, R, Lu, Z., \& Ye, K. (2010). How do firms react to the prohibition of long-lived asset impairment reversals? Evidence from China, J.Account. Public Policy, 29, 424-438. 